\title{
POTENSI PENGEMBANGAN APLIKASI MULTIMEDIA SEBAGAI MEDIA KOMUNIKASI PERSUASIF DI SOSIAL MEDIA
}

\author{
Sigit Pamungkas
}

\begin{abstract}
Abstrak
Salah satu pendekatan yang sering digunakan dalam berkomunikasi adalah Komunikasi Persuasif; yaitu suatu pendekatan komunikasi yang bertujuan mengajak atau mempengaruhi orang lain untuk melakukan sesuatu, tanpa adanya unsur-unsur paksaan. Pendekatan komunikasi persuasif sangat beragam. Salah satu di antaranya adalah Komunikasi Persuasif menurut Aristotle, yaitu: Argumen yang bersifat logis, argumen yang bersifat psikologis dan argumen berdasarkan kredibilitas si pemberi argumen. Setiap orang memiliki keunikan tersendiri untuk dipersuasi, serta cenderung bisa dipersuasi dengan salah satu pendekatan tersebut secara dominan. Praktek komunikasi persuasif melalui media sosial semakin tidak terbendung. Pesan komunikasi yang dikirim dalam format digital sangat mudah dimanipulasi, hal ini memicu kreatifitas para komunikatornya. Salah satu bentuk kreatifitas yang dikembangkan adalah game interaktif yang bisa dikategorikan sebagai produk multimedia. Tulisan ini bertujuan untuk memaparkan besarnya potensi dan peluang bagi praktisi industri kreatif dan multimedia di Indonesia. Selain karena banyaknya pengguna sosial media, kebutuhan untuk terus memberikan persuasi (promosi ataupun kampanye)melalui media online terus meningkat. Tulisan ini juga berisi paparan usulan dari penulis tentang aplikasi multimedia edukatif hasil dari penelitian penulis yang didanai oleh DIKTI pada bulan Juli Desember 2013 lalu.
\end{abstract}

Kata kunci: Media Pembelajaran, Media Sosial, Multimedia, Komunikasi Persuasif, Pengambilan Keputusan

Setiap hari manusia diperhadapkan pada berbagai pilihan. Keputusan terhadap suatu pilihan yang kita lakukan hari ini akan memberikan konsekuensi di hari esok. Godaan untuk melakukan keputusan yang tidak penting menjadi tantangan sehari-hari bagi kita setiap saat. Contohnya ketika kita membuka internet untuk mengecek email, ataupun sekedar ingin mengecek status teman-teman yang tergabung dalam akun sosial media, kita bisa melihat berbagai bannerdan link berita yang judulnya sangat provokatif. Gambar pada banner dan judul tersebut dirancang untuk membuat kita terbujuk agar kita mengakses link tersebut. Dalam konteks Ilmu Komunikasi, proses membujuk seseorang tanpa membuat orang tersebut merasa dipengaruhi, biasa disebut sebagai proses mempersuasi seseorang.

Salah satu konsep komunikasi yang mempengaruhi pengambilan keputusan adalah Komunikasi Persuasif (Maulana \& Gumelar, 2013, 7). Pada dasarnya definisi atau pengertian komunikasi persuasi adalah kemampuan komunikasi yang 
dapat membujuk atau mengarahkan orang lain untuk melakukan sesuatu sesuai kemauan komunikator.

Hal ini sering diterapkan dalam produksi iklan, promosi, kampanye, serta kegiatan yang lain. Berbagai cara dilakukan untuk membujuk agar audiens melakukan sesuatu sama seperti yang dikehendaki oleh si pembujuk. Terlebih di tahun 2014 ini, ketika para caleg dari masing-masing partai politik berlomba-lomba untuk memenangkan pemilu legislatif dan pilpres. Ajakan yang bersifat kreatif, unik dan menarik perhatian membuat si caleg akan mudah diingat oleh publik. Sebaliknya, cukup banyak juga oknum caleg dan tokoh politik yang mendiskreditkan lawan politiknya dalam berkampanye.

Tindakan black campaign (kampanye yang mendiskreditkan lawan politik namun tidak berdasarkan fakta) maupun negative campaign (kampanye yang mendiskreditkan lawan politik, menggunakan fakta yang ada)semakin tak terhindarkan. (hukumonline 2007)

Konten kampanye tersebut makin mudah menyebar berkat kemajuan teknologi media, khususnya internet dan sosial media. Publik yang pro, akan dengan mudah menyebarkan konten tadi ke lingkaran komunitasnya, sedangkan publik yang kontra bisa kan memberi opini bersifat kontra melalui fasilitas komentar yang tersedia. Link informasi yang mendukung opini tersebut juga dengan mudah dilampirkan pada fasilitas komentar.

\section{Metodologi}

Penelitian ini menggunakan pendekatan kualitatif dengan cara studi literatur dan pengamatan langsung. Kirk dan Miller (1986,9) mengungkapkan penelitian kualitatif sebagai suatu tradisi tertentu dalam ilmu sosial yang secara mendasar bergantung pada manusia dalam kawasannya tersendiri terkait dalam bahasa dan istilah yang digunakan di dalamnya. Sedangkan metodologi kualitatif menurut Bogdan dan Taylor (Moleong, 2007, 3) adalah suatu prosedur penelitian yang hasil akhirnya berupa data-data bersikap deskriptif, dalam bentuk kata tertulis, maupun secara lisan dari orang-orang dan perilaku yang diamati. 
1. Data yang dikumpulkan oleh penulis adalah data melalui pengamatan langsung dari obyek penelitian. Dalam hal ini adalah pesan-pesan persuasif yang terjadi dalam sejumlah media online, yang terhubung dengan sosial media facebook, youtube dan twitter.

2. Selain menggunakan buku-buku literatur, penulis juga menggunakan hasil penelitian yang dilakukan penulis sebelumnya. Penelitian tersebut berjudul; Pengembangan Prototip Komik Multimedia Sebagai Media Pembelajaran Simulasi Pengambilan Keputusan. Penelitian tersebut didanai oleh DIKTI ( Juli - Desember 2013)dan telah selesai dilaksanakan. Hasil akhir dari penelitian tersebut adalah sebuah produk prototip aplikasi multimedia edukatif dalam bentuk CD-ROM yang bisa diakses menggunakan computer. Prototip produk inilah yang menjadi salah satu acuan referensi penulisan.

\section{HASIL}

Pada tahap ini, topik bahasan dibagi menjadi beberapa sub topik, yaitu;

\section{Penerapan Komunikasi Persuasif Pada Bidang Politik}

Dalam ranah ilmu komunikasi, komunikasi untuk mengajak publik melakukan sesuatu tanpa ada unsur paksaan dikenal dengan isitilah komunikasi persuasif. Misal seorang capres dari partai tertentu berniat untuk mempersuasi warga agar memilihnya pada pilpres 2014. Maka konten kampanye yang dikomunikasikan kepada publik akan sangat beragam. Mulai dari penggunaan bintang iklan sebagai endorser, opini dari pakar politik, hingga informasi prediktif yang secara psikologis memberikan ketakutan kepada publik jika lawan politiknya yang menang. Yustiman Ihza mengungkapkan tentang tiga jenis pola dasar pengambilan keputusan dari publik yang dipersuasi yang menurut Rank, Monroe dan Lewis, yang juga dicetuskan oleh Aristotle, yaitu ethos, pathos dan logos ( Ihza 2013, 74). Penerapan pendekatan komunikasi persuasi ini bisa diterapkan dalam banyak hal. Contohnya dalam kasus kampanye pilpres, pendekatan berkampanya bisa dibagi menjadi;

1) pendekatan ethos, yaitu dasar pengambilan keputusan berdasarkan kredibilitas seseorang. Misalnya persuasi dari seorang pakar politik, atau 
tokoh masyarakat yang dipercaya kepada audiens agar memilih capres tertentu. Diharapkan kredibilitas si pakar ataupun tokoh masyarakat akan lebih mudah diterima oleh publik. Pada contoh produk komersial, misalnyaanjuran seorang dokter gigi untuk memilih pasta gigi tertentu diharapkan akan lebih mudah diterima oleh publik.

2) pendekatan pathos, yaitu dasar pengambilan keputusan berdasarkan faktorfaktor psikologis dan emosional. Misalnya si juru kampanye memilih untuk menggunakan elemen "ketakutan" dalam mempersuasi publik. Si juru kampanye akan menyampaikan dampak buruk yang mungkin terjadi jika publik tidak memilih capres tertentu. Dengan demikian publik akan cenderung terbujuk untuk memilih capres yang didukung si komunikator. Penerapan pendekatan ini pada promosi produk pasta gigi, adalah secara psikologis menakuti publik dengan penderitaan akibat kerusakan gigi jika tidak menggunakan pasta gigi tertentu.

3) pendekatan logos, adalah dasar pengambilan keputusan berdasarkan datadata yang logis dan bisa dipertanggungjawabkan. Seorang jurkam akan mempersuasi publik dengan memberikan bukti-bukti ilmiah dan data-data terpercaya yang mendukung persuasinya. Misalnya tentang rekam jejak capres yang diusungnya, visi dan misi, serta prestasi yang pernah dibuatnya. Dalam konteks promosi produk pasta gigi, audiens akan disuguhkan data medis, bahwa setiap jam bakteri di dalam mulut akan berkembang biak sangat cepat jika gigi tidak disikat menggunakan pasta gigi merk tertentu.

Media yang digunakan untuk mempersuasi publik dan target audience wujudnya sangat beragam. Mulai dari gambar digital grafis yang bersifat statis hingga video game yang bersifat interaktif. Apapun format medianya, tujuannya sama, yaitu untuk mempersuasi publik melakukan agar mau melakukan kehendak sang komunikator. 


\section{Praktek Manipulasi Pesan Persuasif Melalui Sosial Media}

Media online, khususnya sosial media telah menjadi media favorit dalam mengkomunikasikan pesan.Salah satu penyebabnya adalah karena sifat dari media online yang convergence. Terry Flew dalam bukunya New Media an Introduction mengungkapkan tentang sifat convergence ini (Flew 2008, 22-23);

...Convergence refers in the first instance to the interlinking of computing and IT, communications networks, and media content that occurred with the development and popularization of the internet, and theconvergent products, services, and activities that have emerged in digital media space.

...The second element of convergence is the morphing of devices(computers, mobile phones, television, etc) as they become multi-purppose conduit for a range of activities involving digita media.

Dari uraian Terry Flew di atas, dapat disimpulkan bahwa perkembangan teknologi informasi memungkinkan pengkonversian data teks, grafik, audio ataupun video ke dalam format digital. Informasi apapun, sepanjang sudah dikonversi ke dalam data digital akan mudah didistribusikan ke berbagai media dan perangkat digital. Sebagaimana kita ketahui bahwa telepon seluler generasi sekarang memunginkan penggunanya untuk mengakses koran online (teks dan grafik), radio online(audio) dan juga TV online. Penyebaran informasi tersebut didukung dengan makin berkembangnya social media yang memungkinkan pemiliknya untuk membagikan sebuah pesan.

Seperti diberitakan oleh Kemkominfo bahwa Indonesia adalah peringkat ke empat negara pengguna facebook terbesar di dunia (Kemkominfo 2014). Hal inilah yang dimanfaatkan oleh berbagai partai politik untuk mempersuasi sebanyak mungkin pengguna facebook agar mendukung partai mereka. Arus komunikasi dan pertukaran informasi yang terjadi di sosial media, termasuk facebook, twitter dan sosial media lainnya menjadi kian tak terbendung. Selain mudah disebarkan (networkable), informasi dalam bentuk digital juga mudah dimanipulasi (manipulable). Kemudahan memanipulasi data digital pada satu sisi sangat memacu kreatifitas, tapi pada sisi lain sangat rentan terhadap resiko pendistorsian makna sebuah pesan. 


\section{Gambar 1. Screenshot berita tentang parodi politik capres boneka dari situs solopos}

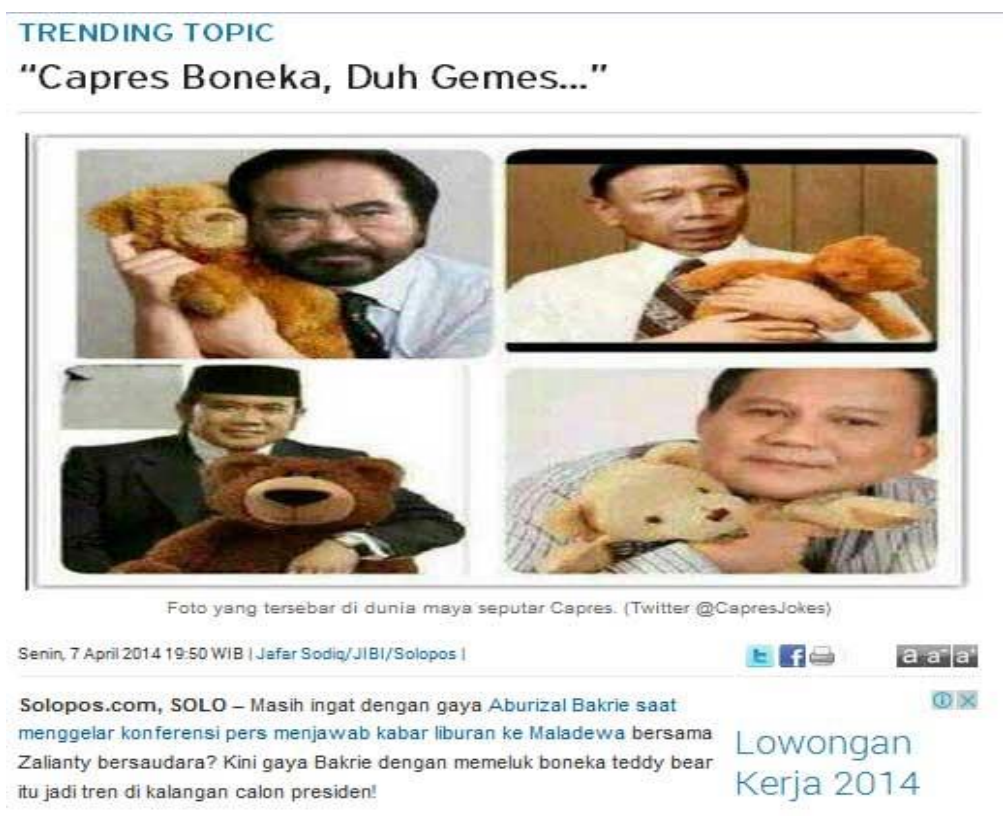

Sumber :situs berita solopos.com, 7 April 2014, diakses tanggal 19 Mei 2014.

Gambar 2. Foto manipulasi parodi politik capres boneka

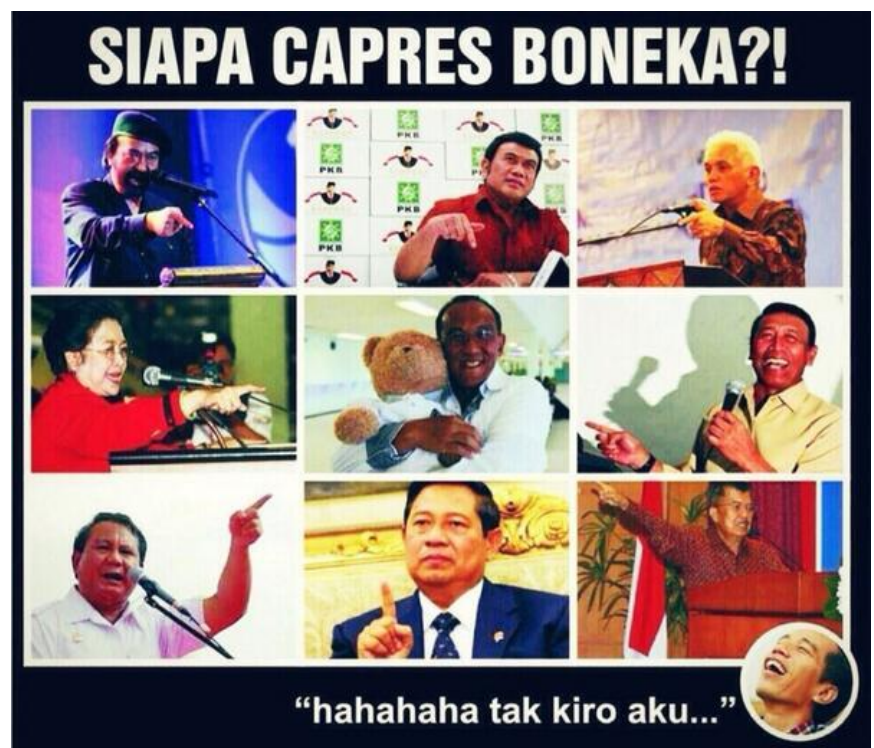

Sumber :Situs berita solopos.com, 3 April 2014, diakses tanggal 19 Mei 2014

Gambar 1 dan gambar 2 adalah contoh bentuk manipulasi gambar yang bisa dibilang kreatif dalam sisi ide, namun tidak akurat dalam segi pesan. Kreatif karena 
81 - Potensi Pengembangan Aplikasi Multimedia Sebagai Media Komunikasi ......

berhasil menciptakan sebuah pesan baru dalam bentuk informasi grafik dari penggabungan gambar-gambar grafik yang ada sebelumnya.Tidak akurat, karena memang pesannya cenderung didistorsi sesuai selera si manipulator gambar. Cukup sulit untuk melacak penyebar pertama dari gambar-gambar tersebut. Awal beredarnya gambar tersebut biasanya dimulai di komunitas online (sosial media, microblog, forum) ataupun instan messaging (LINE, Whatsapp, Blackberry Messenger,dan sebagainya). Setelah gambar itu populer dan menjadi trending topic, media mainstream lokal ataupun nasionaltidak akansegan-segan untuk mengulasnya. Dua contoh di atas mungkin hanya bernuansa guyon politik. Namun banyak fotofoto hasil manipulasi lain pesannya benar-benar ekstrim mendiskreditkan tokoh politik tertentu seperti terlihat pada gambar 3 .

\section{Gambar 3. Berita tentang black campaign dalam bentuk manipulasi grafis}

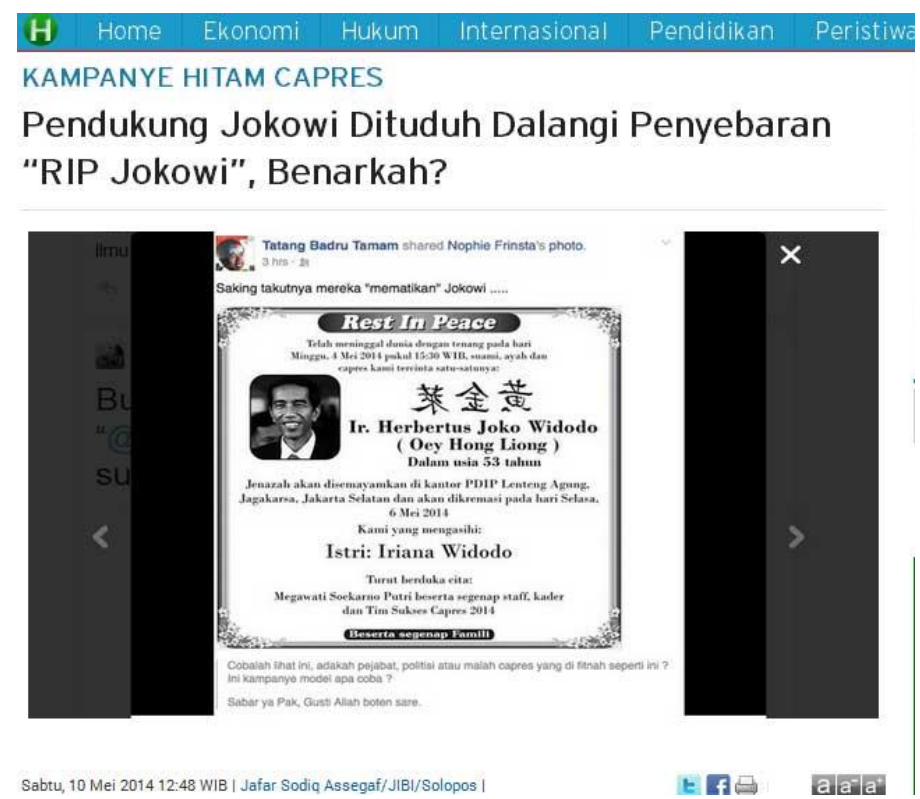

Sumber :Situs berita harianjogja.com, 10 Mei 2014, diakses tanggal 19 Mei 2014

Jika dikaitkan dengan konsep komunikasi persuasif, pendiskreditan tokoh politik tertentu bisa dikategorikan sebagai bentuk komunikai persuasif menggunakan pendekatan pathos (emosional).

Kreatifitas yang bermunculan melalui sosial media bukan hanya sebatas pada gambar grafik dan video, tetapi juga video game. Sekitar awal tahun 2014, penggemar gadget berbasis android digemparkan oleh game flappy bird, yang 
menurut berita, keuntungannya sempat mencapai sekitar 600 juta rupiah perhari. Game online tersebut telah diadopsi juga menjadi game bernuansa politik seperti terlihat pada gambar 4 .

\section{Gambar 4. Berita tentang tentang game Jokowi}

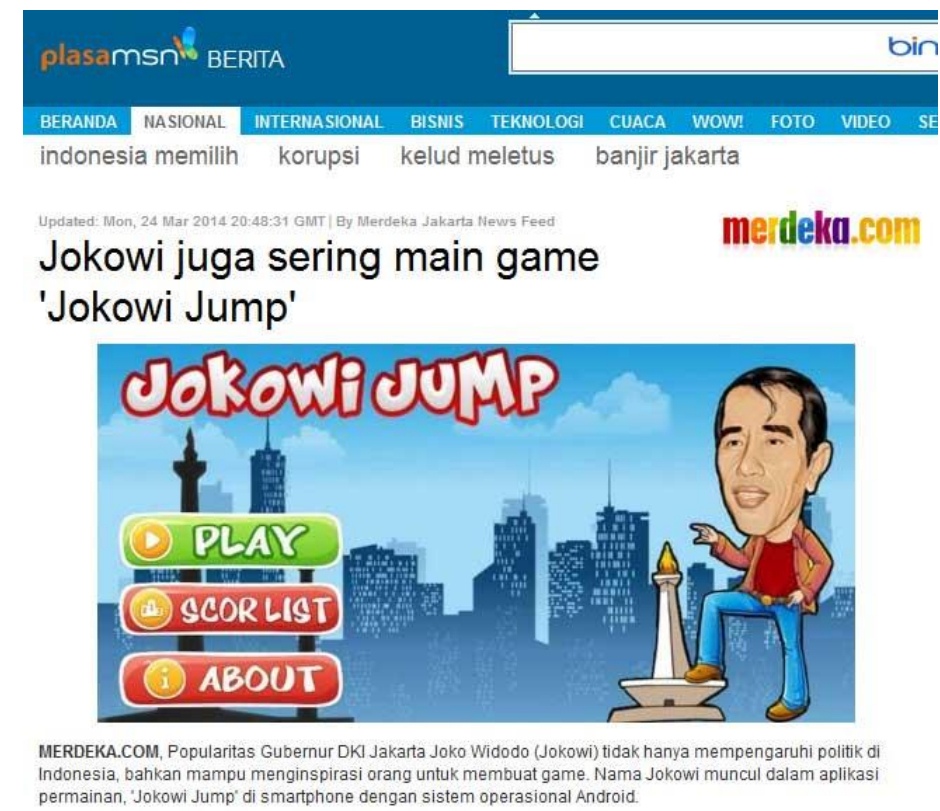

Sumber : Situs berita.plasa.msn.com, 24 Maret 2014, diakses tanggal 19 Mei 2014.

Video game tersebut memang tidak secara frontal mempersuasi pengguna untuk mendukung tokoh utamanya Joko Widodo. Namun secara psikologis, ketika memainkan sebuah game, si pemain akan cenderung berpihak ke tokoh utama dalam game tersebut. Mungkin si pembuat game belum memperoleh pendapatan finansial setinggi game flappy bird, namun jika tujuan pembuatan game adalah untuk mensosialisasikan si tokoh utama game (sekaligus jagoan politiknya), maka setidaknya tokoh game tersebut mulai dikenal oleh para gamer terlepas dari apapun kebijakan politiknya.

Video clip game, dan kartun grafis adalah contoh industri kreatif berbasis multimedia digital dan mudah disebar melalui media online dan. Contoh-contoh di atas menunjukkan bahwa media-media tersebut menjadi media alternatif untuk mempersuasi publik.Game adalah salah satu bentuk aplikasi multimedia yang bukan hanya sekedar media hiburan. Potensi dari video game menurut Beck dan Wade (2007, xiv) adalah sebagai berikut 
...,kita hanya mempelajari sekitar 10 persen dari apa yang kita tonton, tetapi lebih dari 70 persen dari apa yang kita lakukan. Dan dalam masa pertumbuhan anakanak, pembelajaran dari game akan jauh lebih melekat dan berpengaruh.

Berdasarkan opini di atas, sudah sangat wajar jika bermunculan pihak pengembang aplikasi multimedia maupun institusi akademis berusaha menciptakan game yang bersifat edukatif .Gambar 5 menunjukkan sebuah situs pengembang multimedia game yang juga memproduksi game edukatif.

\section{Gambar 5}

Situs penyedia game edukasi

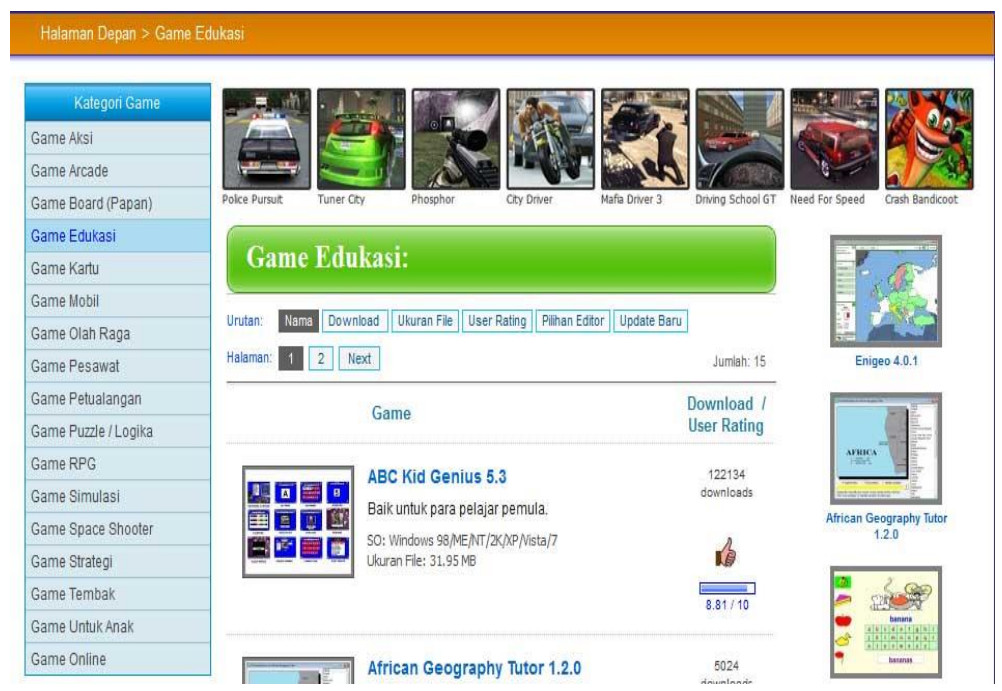

Sumber :situsgamegratis33.com, diakses tanggal 19 Mei 2014.

Dengan memperhatikan besarnya kebutuhan promosi persuasif kepada publik pengguna sosial media, maka peluang untuk berkarya menciptakan produk multimedia sesuai tuntutan tersebut sangat besar.

\section{Promosi Video Berbasis Kecenderungan Selera Penonton Pada Situs Youtube.}

Salah satu situs video sharing yang populer adalah situs Youtube.Situs ini memungkinkan pengakses internet untuk melihat tayangan video yang telah diunggah oleh pengguna akun youtube.Mayoritas video yang tertayang di situ bisa diakses tanpa harus masuk ke akun youtube.Beberapa bentuk video kampanye politik juga turut dipopulerkan melalui situs ini.Contohnya adalah video kampanye 
pemilihan Gubernur dan Calon Wakil Gubernur DKI Jakarta pada putaran ke dua pada tahun 2012 yang lalu. Kedua calon yang berkompetisi yaitu pasangan Joko Widodo - Basuki Tjahaja Purnama melawan Fauzi Bowo- Nachrowi Ramli masingmasing berusaha mempersuasi warga Jakarta untuk memilihnya melalui berbagai video kampanye (gambar 6 dan gambar 7).

\section{Gambar 6. Video kampanye persuasif pendukung kubu Joko Widodo.}

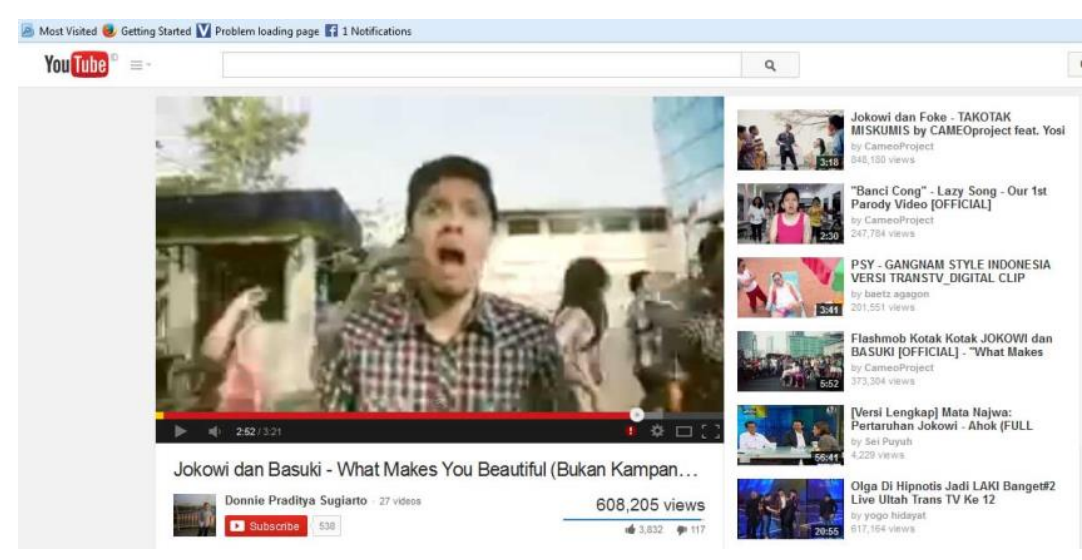

Sumber :Situs youtube dari akun Donnie Praditya Sugiarto, diunggah 26 Agustus 2012, diakses 19 Mei 2014.

\section{Gambar 7. Video kampanye persuasif pendukung kubu Fauzi Bowo}

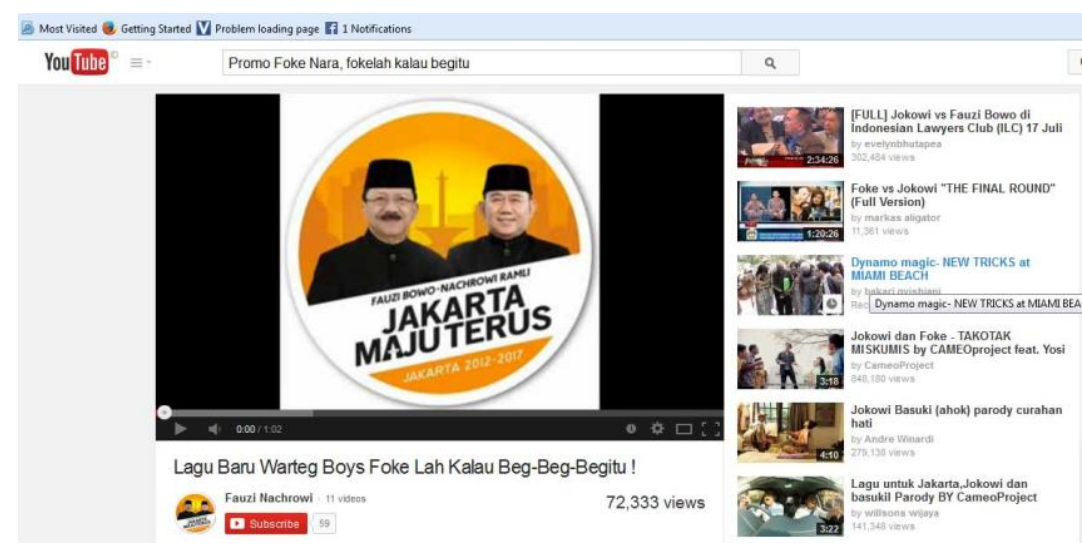

Sumber :Situsyoutube.com dari akun Fauzi Nachrowi, diunggah 12 Mei 2012, diakses 19 Mei 2014.

Salah satu keunikan dari situs Youtube, situs ini mampu mengidentifikasi kecenderungan selera si penonton. Seandainya seorang penonton gemar menonton 
video politik tokoh tertentu, maka youtube akan merekomendasikan video-video dengan tema sejenis.

\section{Gambar 8. Tayangan debat politik yang bisa diakses di situs Youtube}

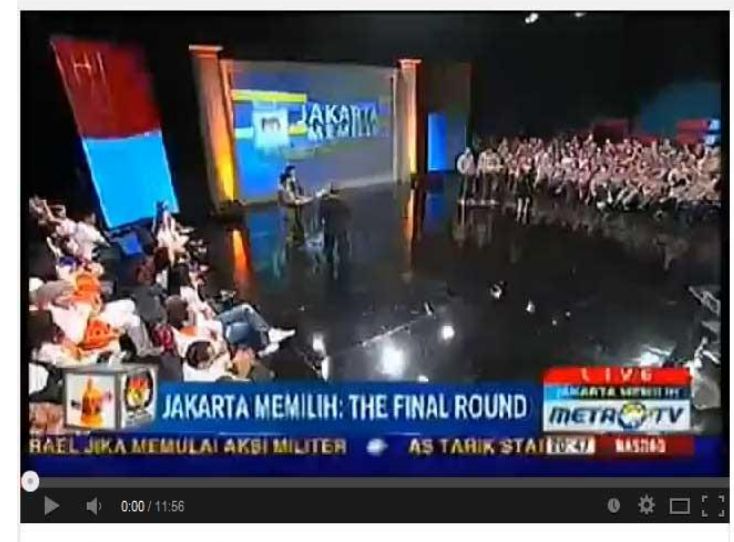

SERU, Debat Nachrowi (Nara) VS Basuki (Ahok). [Cawagubnya...

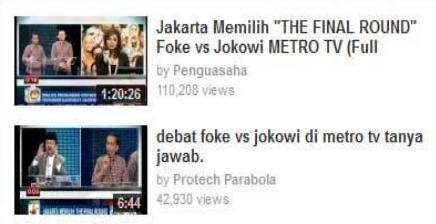

jawab.

\begin{tabular}{l|l} 
Debat Cagub DKI Putaran Kedua Foke \\
vs Jokowi di JAKTV (Full Version plus
\end{tabular}

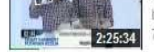
vs Jokowi di Penguasaha
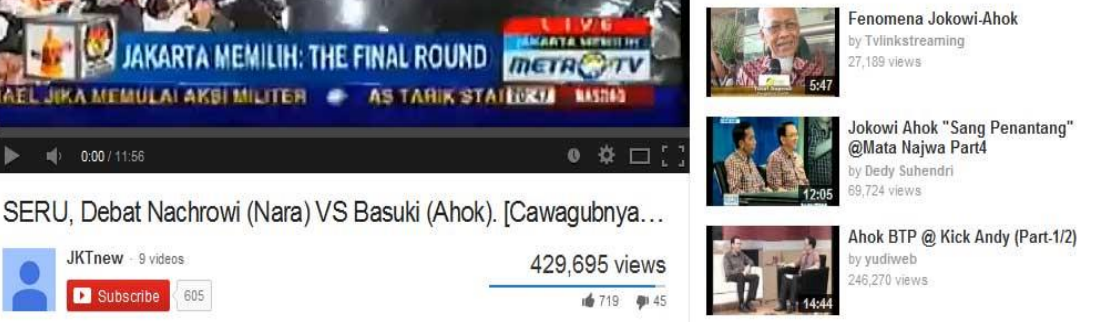

Sumber :Situs youtube.com dari akun JKTnew, diunggah 16 September 2012, diakses 19 Mei 2014

Tema utama dari video di atas adalah adu argumentasi antara dua cawagub, yaitu Nachrowi (Nara) dan Basuki (Ahok). Sedangkan gambar thumbnail di samping kanan adalah video-video yang relevan dengan konten video yang sedang diakses.Video-video tersebut direkomendasikan oleh Youtube, selain karena sesuai dengan tema, juga karena mekanisme pada situs ini mampu mendeteksi kecenderungan perilaku penonton sebelumnya. Akumulasi dari tema pilihan penonton inilah yang menjadi dasar rekomendasi dari Youtube dalam merekomendasikan video-video lain.

Merujuk pada fenomena di atas, adalah sangat penting untuk mengetahui kecenderungan perilaku pengguna internet (termasuk penonton Youtube). Terkait dengan konsep komunikasi persuasif, sangat penting untuk mengetahui jenis-jenis pendekatan persuasi yang cocok bagi calon audiens.Berdasarkan hal ini, penulis telah melakukan penelitian yang bertujuan untuk menciptakan sebuah rancangan aplikasi multimedia untuk mendeteksi jenis pendekatan persuasif yang paling sesuai bagi seseorang.Melalui aplikasi multimedia ini, pengguna bisa memperoleh gambaran, apakah dia cenderung mudah dipersuasi dengan pendekatan ethos, 
ataukah logos ataukah pathos. Lebih detail tentang hal ini akan dibahas pada bab berikutnya.

\section{Pembahasan}

\section{Prototip Aplikasi Multimedia Edukatif Untuk Mengukur Kecenderungan Pertimbangan Pengambilan Keputusan.}

Pada tahun 2013 lalu, penulis melakukan penelitian Hibah Dosen Pemula yang didanai DIKTI pada tahun 2013, dengan judul; Pengembangan Prototip Komik Multimedia Sebagai Media Pembelajaran Simulasi Pengambilan Keputusan. Salah satu hasil akhir penelitian tersebut adalah sebuah prototip aplikasi multimedia yang dikemas dalam bentuk CD-ROM dan bisa diakses menggunakan komputer, seperti terlihat pada gambar 9 .

\section{Gambar 9. Kemasan prototip komik multimedia usulan penulis}

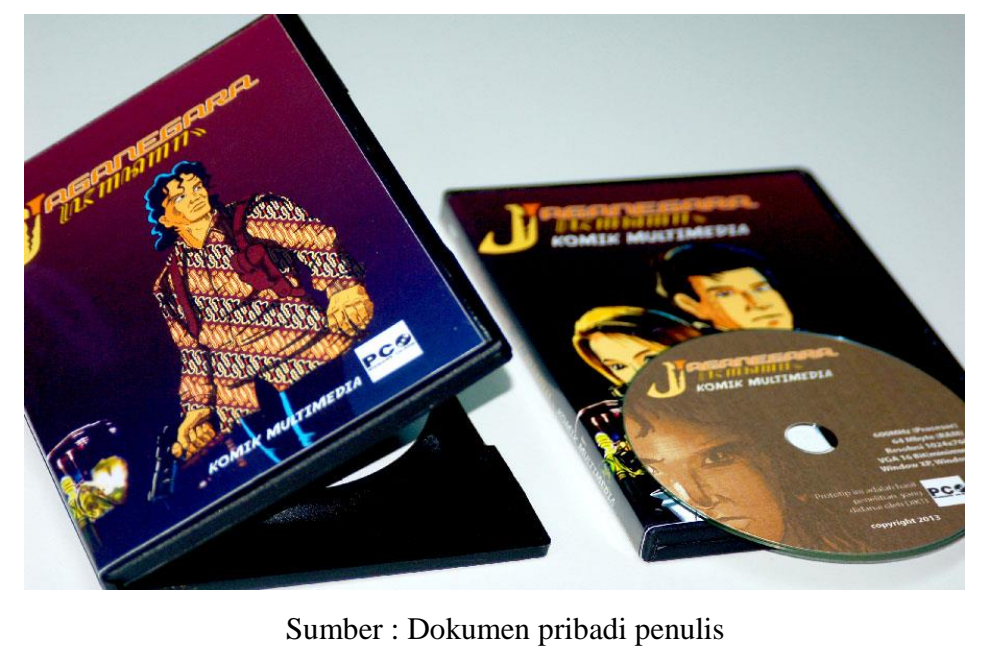

Istilah multimedia yang penulis gunakan adalah mengacu pada elemenelemen multimedia yang diuraikan oleh Tay Vaughan, bahwa multimedia adalah kombinasi teks, grafik, suara, animasi, dan video yang bisa diakses dengan menggunakan komputer atau gadget digital yang lain. Ketika seluruh elemen multimedia digabungkan (gambar, animasi, suara, video, dan informasi teks), maka hal ini akan menjadi sebuah presentasi sensasional yang lebih komunikatif disbanding media lain yang berdiri sendiri (Vaughn 2011, 18 - 164). 
Tujuan dari pengembangan produk ini adalah sebagai media pembelajaran pengambilan keputusan.Wina Sanjaya mengungkapkan tentang definisi media pembelajaran yang disampaikan oleh Rossi dan Breidle (1966) bahwa seluruh elemen media(dan multimedia) bisa digunakan sebagai media pembelajaran (Sanjaya 2012, 58) Media pembelajaran adalah seluruh alat dan bahan yang dapat dipakai untuk tujuan pendidikan seperti radio, televisi, buku, koran, majalah dan sebagainya. Dalam buku yang sama, Wina Sanjaya juga mengungkapkan bentukbentuk pembelajaran yang dihasilkan melalui media komputer klasifikasi tentang jenis-jenis praktek pembelajaran menurut Heinich. ( Sanjaya 2012, 200), yaitu ;

a) praktek dan latihan (drill and practice)

b) tutorial

c) permainan(games)

d) simulasi (Simulation)

e) penemuan(Discovery)

f) pemecahan masalah(Problem Solving)

Pada penelitian yang dibuat penulis, jenis pembelajaran yang hendak dirancang adalah simulasi pengambilan keputusan. Uraian tentang simulasi yang diterapkan pada program ini, meliputi tindakan pengambilan keputusan yang harus dibuat oleh si pengguna beserta resiko, konsekuensi yang akan dialami, serta alasan pemilihan pengambilan keputusan itu (Sanjaya 2012, 204).

Program simulasi adalah program yang berupaya melibatkan siswa dalam persoalan yang mirip dengan situasi yang sebenarnya, namun tanpa resiko nyata. Melalui program simulasi, peserta didik diajak untuk membuat keputusan yang tepat dari beberapa alternatif solusi yang ada. Setiap keputusan yang diambil akan memberikan dampak tertentu.

Sebagaimana terlihat pada gambar 10, aplikasi multimedia yang penulis rancang adalah cerita yang disajikan dalam bentuk gambar komik. Cerita terdiri dari tujuh babak, dan setiap babak terdiri dari beberapa gambar. 
Gambar 10.Tampilan adegan komik

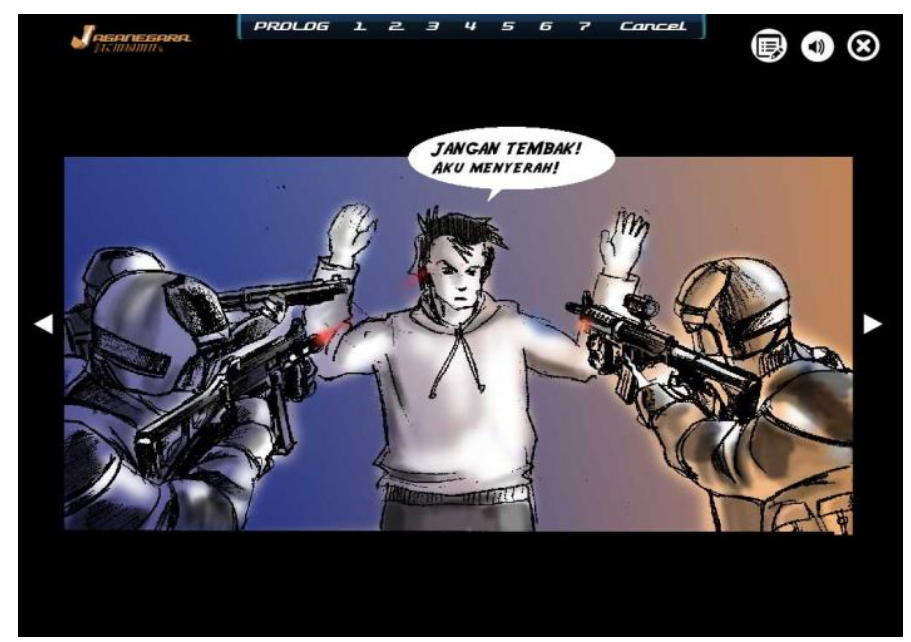

Sumber : Dokumen pribadi penulis

Di akhir setiap bab, pengguna harus melakukan pengambilan keputusan. Dalam aplikasi ini, pengguna akan diberikan dua buah pilihan langkah seperti yang terlihat pada gambar 11 .

Gambar 11. Pengambilan Keputusan

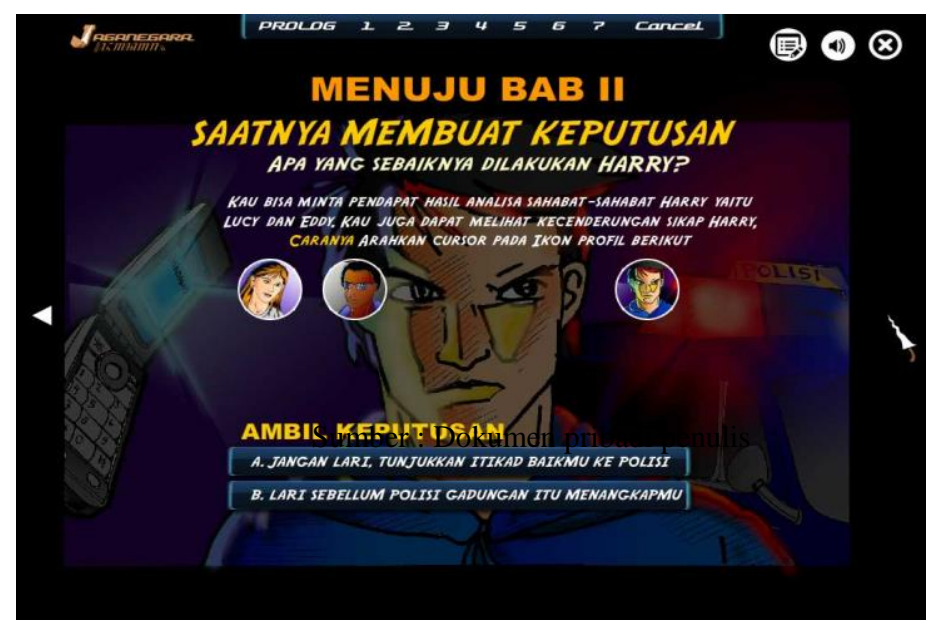

Pada gambar 11 di atas terlihat tombol opsi A dan opsi B beserta keterangan yang menjelaskan tindakan opsi tersebut. Setiap keputusan opsi yang diberikan oleh pengguna akan memberikan konsekuensi cerita yang berbeda satu dengan yang lain. Setelah pengguna memberikan opsi, pengguna juga akan diminta untuk memberikan alasan yang melatarbelakangi pilihannya seperti terlihat pada gambar 12 . 
Gambar 12. Instrumen pengukur dasar-dasar pengambilan keputusan

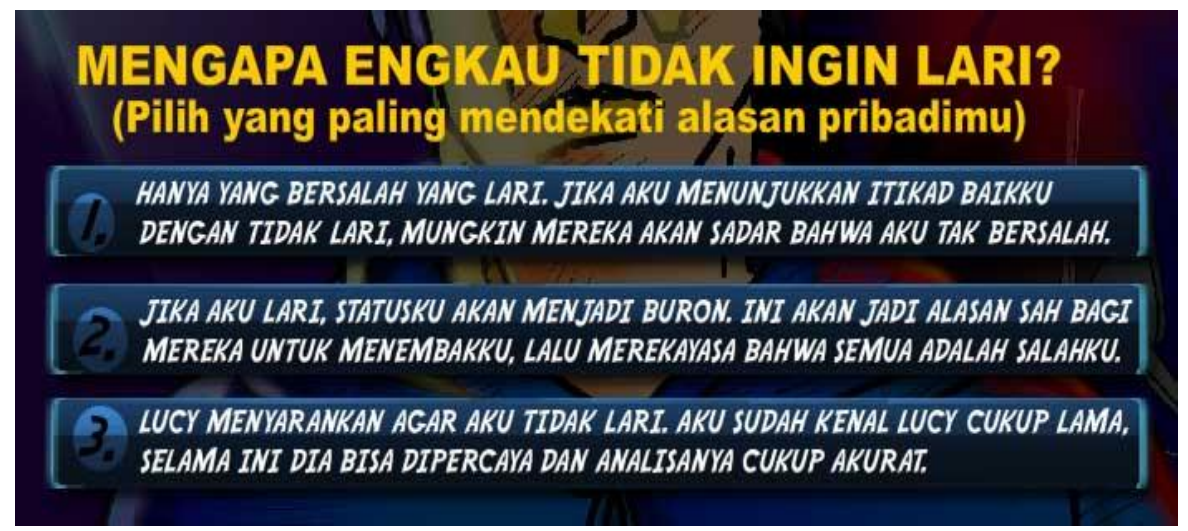

Sumber : Dokumen pribadi penulis

Pada gambar 12 terlihat tiga buah pertanyaan yang muncul setelah pengguna memberikan pilihan. Pertanyaan ini hanya muncul setelah pengguna memberikan pilihan keputusan seperti yang terlihat pada gambar 12.Pengguna diminta untuk memberikan pilihan yang paling mendekati dengan alasan pengambilan keputusannya secara pribadi. Ketiga pertanyaan tersebut dibuat dengan mengacu pada konsep komunikasi persuasive (berdasarkan pertimbangan ethos, logos ataupun pathos). Apapun alasan yang dipilih, sistem akan merekam kecenderungan dasar pertimbangan yang sesuai dengan pengguna, entah itu pertimbangan ethos, logos ataupun pathos. Selanjutnya pada babak berikutnya, pengguna akan dihadapkan lagi pada pilihan serupa. Di akhir cerita sepanjang tujuh bab, sistem pada aplikasi ini akan memberikan jumlah akumulasi kecenderungan pilihan dasar yang telah dilakukan si pengguna. Pengguna akan memperoleh hasil, entah dia cenderung menggunakan pertimbangan ethos, logos ataupun pathos.

Namun demikian, karena keterbatasan waktu penelitian, produk ini baru selesai dalam bentuk prototip. Konten produk ini berisi cerita satu babak beserta alternatif pilihan cerita ke babak berikutnya disertai pertanyaan yang akan mengidentifikasi kecenderungan dasar pertimbangan (ethos, logos atau pathos) yang digunakan oleh pengguna. 


\section{Kesimpulan}

Artikel ini berisi ulasan tentang praktek komunikasi persuasif melalui media internet, khususnya social media.Artikel ini juga mengulas potensi pengembangan konten digital berdasarkan kebutuhan dan fasilitas yang tersedia. Konklusi akhir dari tulisan ini adalah ;

1) Komunikasi Persuasif adalah bentuk komunikasi yang membujuk orang lain untuk melakukan sesuatu sesuai kehendak si pembujuk, termasuk dalam hal pengambilan keputusan. Karena itu Komunikasi Persuasif berperan sangat penting dalam mempengaruhi manusia dalam menentukan keputusan.

2) Secara umum, ada tiga pendekatan yang mempengaruhi dasar-dasar seseorang dalam membuat keputusan. Yaitu pertimbangan ethos (pertimbangan keputusan berdasarkan anjuran tokoh yang dipercaya), logos (pertimbangan keputusan berdasarkan alasan-alasan logis) dan pathos (pertimbangan keputusan berdasarkan alasan-alasan psikologis)

3) Setiap hari manusia dihadapkan dengan berbagai pilihan tindakan keputusan. Dan karenanya setiap hari manusia akan berhadapan dengan berbagai bujukan (persuasi) secara lisan maupun melalui media, terutama di tahun 2014 ini, ketika seluruh warga Negara Indonesia akan menyelenggarakan pemilihan presiden dan wakil presiden

4) Media online, khususnya social media telah menjadi media yang sangat populer bagi berbagai pihak untuk melakukan berbagai bentuk komunikasi (termasuk komunikasi yang persuasif). Karena sifat datanya yang berbentuk digital, maka konten yang dikomunikasikan melalui social media sangat mudah untuk didistribusikan ke format-format lain, sekaligus sangat mudah untuk dimanipulasi.

5) Kemudahan untuk memanipulasi pesan persuasif dalam bentuk data digital telah memicu kreatifitas para praktisi multimedia. Bentuk manipulasi pesan antara lain manipulasi gambar digital, parody video, serta video game. Tujuan dari manipulasi data digital tadi tetap sama, yaitu untuk mempersuasi audiens. Sebagian dimanipulasi sedemikian rupa sesuai dengan tujuan 
komunikator, sebagian dimanipulasi lagi menjadi benar-benar bertolak belakang dengan tujuan awal komunikator.

6) Berdasarkan potensi jumlah pengguna social media di Indonesia, dan jumlah kebutuhan akan pesan komunikasi persuasif yang kreatif, maka penulis mengadakan penelitian tentang pengembangan aplikasi multimedia. Tujuan dari penelitian ini adalah membuat prototip produk multimedia yang bisa dipergunakan untuk mengukur kecenderungan dasar-dasar pengambilan keputusan si pengguna (ethos, logos, pathos).

7) Penelitian yang didanai oleh DIKTI tersebut telah selesai dilakukan pada sekitar bulan Juli hingga Desember tahun 2013. Judul penelitian tersebut adalah; Pengembangan Prototip Komik Multimedia sebagai Media Pembelajaran Simulasi Pengambilan Keputusan. Hasil akhir komik tersebut sudah dilaporkan ke DIKTI. Salah satu target capaian komik tersebut adalah prototip komik multimedia yang dikemas dalam bentuk CD-ROM, bisa diakses menggunakan computer. Karena masih bersifat prototip, konten dari aplikasi ini masih sangat terbatas. Penulis berrencana untuk melanjutkan penelitian ini pada kesempatan selanjutnya. Tulisan ini adalah tulisan pertama yang dipublikasikan dalam bentuk Jurnal ilmiah, sebagaimana yang ditargetkan oleh penulis pada proposal.

\section{Daftar Pustaka}

Beck, John.C., Wade, Mitchell (2006). The Kids Are Alright: How the gamer generations is changing the workiplace. Harvard Business School Press.

Beck, John.C., Wade, Mitchell (2007). The Kids Are Alright: Gamers Juga Bisa Sukses,Beginilah Cara Generasi Gamer mengubah Lingkungan Kerja. Terj.Isman H.Suryaman. Jakarta : Grasindo.

Flew, Terry(2008). New Media an Introduction. New York : Oxford University Press.

Herdiyan Maulana, Gumgum Gumelar(2013). Psikologi Komunikasi dan Persuasi.Jakarta : Akademia Pratama.

Kirk, Jerome., Miller, Mark. L. (1986).Reliability and Validity in Qualitative Research: Qualitative Research Methods.London :Sage Publication. 
Ihza, Yustiman(2013). Bujuk Rayu Konsumerisme, Menelaah Persuasi Iklan di Era Konsumsi.Jakarta : Linea Pustaka.

Maner, Walter. "Prototyping," Bowling Green State University online. Home page on-line.http://web.cs.bgsu.edu/maner/domains/Proto.html, internet,diakses tanggal 7 Desember 2013.

Moleong, Lexy.J. (2007).Metodologi Penelitan Kualitatif. Bandung : Remaja Rosdakarya.

Morissan(2013). Teori Komunikasi Individu Hingga Massa.Jakarta : Kencana Prenada Grup.

Sanjaya, Wina (2012). Media Komunikasi Pembelajaran.Jakarta : Kencana Prenada Media Grup.

Turner H. Lynn \& Richard West. Pengantar Teori Komunikasi. edisi 2. Jakarta. PT. Salemba Humanika. 2008.

Vaughan, T. Multimedia ; Making It Work $6^{\text {th }}$ ed. Yogyakarta: Penerbit Andi. 2006

Vaughan, T. Multimedia ; Making It Work $8^{\text {th }}$ ed. New York :McGraw Hill. 2011

Werner J.Severin, James W. Tankard, Jr. Teori Komunikasi: Sejarah, Metode, \& Terapan di dalam Media Massa, Edisi ke-5.Jakarta : Kencana Prenada Media Grup. 2011,berita.plasa.msn.com(2014) Jokowi Juga sering Main 'Jokowi Jump'. Dari http://berita.plasa.msn.com/nasional/merdeka/jokowi-jugasering-main-game-jokowi-jump-1, diakses tanggal 19 Mei 2014.

Donnie Praditya Sugiarto, Youtube.com(26 Agustus 2012)Jokowi dan Basuki What Makes You Beautiful (Bukan Kampanye High Definition Video Parody). Dari, http://www.youtube.com/watch?v=XGNK_wuz2zE, diakses tanggal 19 Mei 2014.

Fauzi Nachrowi, Youtube.com(12 Mei 2012)Lagu Warteg Boys Foke Lah Kalau Beg-Beg-Begitu!, Dari, http://www.youtube.com/watch?v=YHcQs8TIPOM, diakses tanggal 19 Mei 2014.gamegratis.com. Game Edukasi. Dari http://www.gamegratis33.com/index.php/category/Game_Edukasi, diakses tanggal 19 Mei 2014.

harianjogja.com(2014) Kampanye Hitam Capres : Pendukung Jokowi Dituduh Dalangi Penyebaran " RIP Jokowi" Benarkah? Dari http://www.harianjogja.com/baca/2014/05/10/kampanye-hitam-caprespendukung-jokowi-dituduh-dalangi-penyebaran-rip-jokowi-benarkah506977, diakses tanggal 19 Mei 2014.

hukumonline.com(2007). Perlu Pembedaan Tegas antara Black dan Negative Campaign. Dari http://www.hukumonline.com/berita/baca/hol17575/perlu- 
93 - Potensi Pengembangan Aplikasi Multimedia Se6agai Media Komunikasi ......

pembedaan-tegas-antara-iblacki-dan-inegative-campaigni, diakses tanggal 19 Mei 2014.

JKTnew, Youtube.com(16 Sept 2012)SERU, Debat Nachrowi (Nara) VS Basuki (Ahok). [Cawagubnya Foke Vs Jokowi] Metro Tv. Dari, http://www.youtube.com/watch?v=CHZFEZGdXtQ, diakses tanggal 19 Mei 2014.

solopos.com(2014) Trending Topic : "Capres Boneka, Duh Gemes...". Dari http://www.solopos.com/2014/04/07/trending-topic-capres-boneka-duh gemes-501031, diakses tanggal 19 Mei 2014.

solopos.com(2014) Trending Sosmed : “Ayo Tebak Siapa Capres Boneka Ya?”. Dari http://www.solopos.com/2014/04/03/trending-sosmed-ayo-tebak-siapacapres-boneka-ya-500232, diakses tanggal 19 Mei 2014. 